ROCZNIKI KULTUROZNAWCZE

Tom/Vol. XII, numer/number 1 - 2021

DOI: http://doi.org/10.18290/rkult21121-7

RAFFAELA GIOVAGNOLI

\title{
RITUALS: PHILOSOPHICAL PERSPECTIVES AND NORMATIVE ASPECTS
}

\section{INTRODUCTION}

The anthropological studies of Ernesto De Martino stress that the experience of the precariousness of human life (rather than natural events and therefore stereotyped behaviors) offer reassuring models to follow by building the same tradition. The sociologist Emile Durkheim and the anthropologist Bronislaw Malinowski analyzed the social function of rituals for the cohesion of communities. Differently, the anthropologists Arnold Van Gennep and Meyer Fortes consider the social and cultural role of the myth that can extend to the religious sphere.

Psychoanalysis investigates the presence of an unconscious ritual in human everyday activities. Obsessive-compulsive personalities create personal rituals; a typical case from ordinary life is to verify that we have closed the gas when we leave our house or that we closed the door. Very common is to walk without stepping on the lines. For the tennis player Nadal is essential to choose the balls or to knock the ball a certain number of times, to align the bottles, to touch parts of the body in a certain way or to clean the lines.

Rituals express personal and social needs with a deep emotional involvement, without which they cease to exist. Rituals require different aesthetic components in different cultures and in different times; the rite must evolve to not lose its meaning. For example, in the religious sphere of Christianity, while for the Western Catholic community the organ sound is perceived as power and becomes a "divine" instrument, for the Eastern Christianity it is perceived as the mere sound of the organ and does not have any sacred sense.

Prof. Raffaela Giovagnoli — Pontifical Lateran University, Rome; e-mail: raffa.giovagnoli@ tiscali.it; ORCID: https://orcid.org/0000-0001-6468-3064. 
Modern studies point the attention on the dynamic of the ritual. For example, Roy Rappaport studied the cyber dimension of the ritual and its implications for ecology and communication.

Religious rites such as bullfighting is experienced by the participants with passion but arouses horror of animal welfarism. More positively, rock concerts or the mega-rallies take the form of a ritual and are experienced with a strong emotional involvement.

We can observe different forms of rituals:

- Initiation rite (for example the initiation of adolescents according to cultural and religious rites, or in Freemasonry rite of passage leading to the grant of the light)

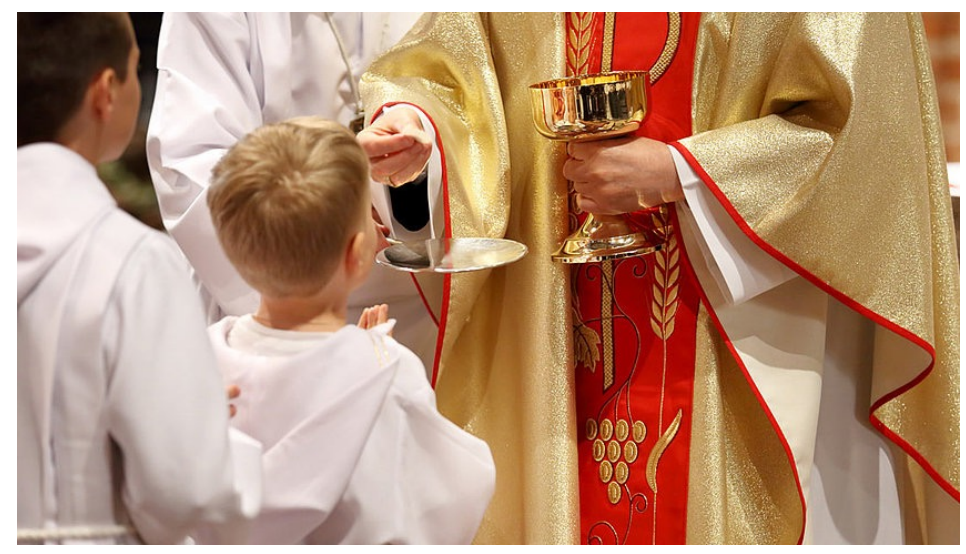

- Rite of passage (Baptism)

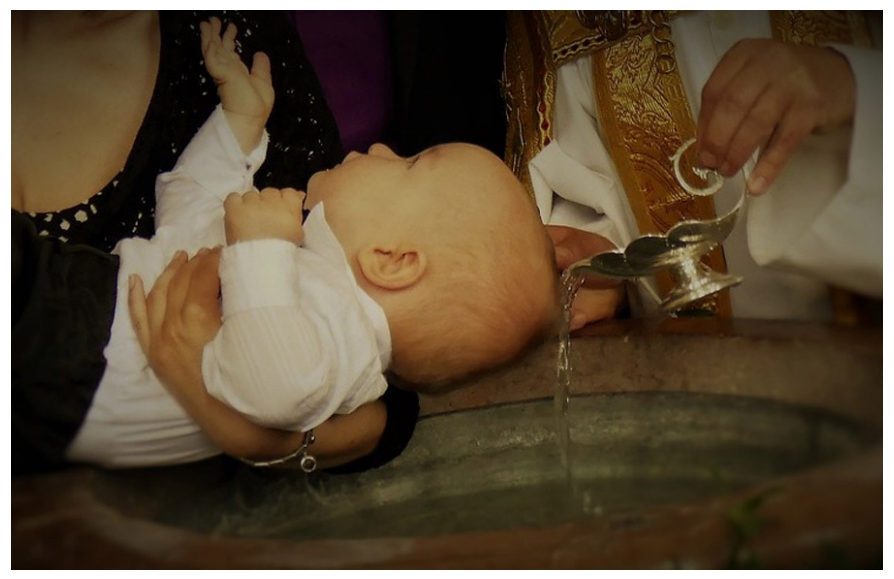


- Propitiatory and apotropaic (ancient rites to propitiate a deity)

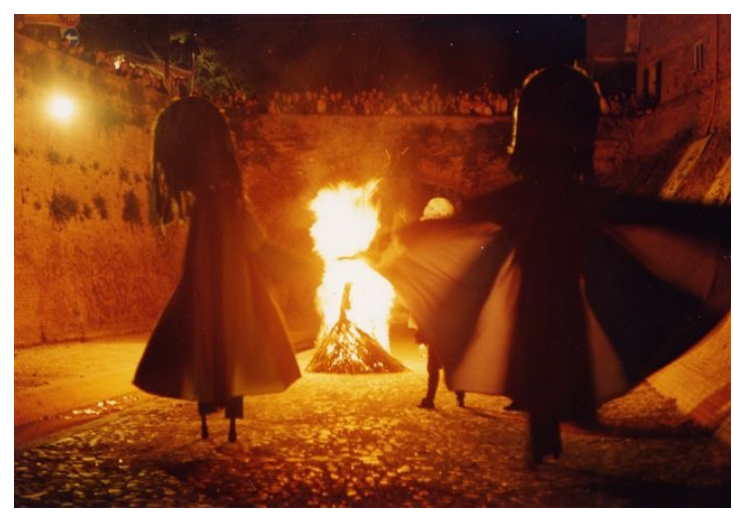

- Recurring rites (ceremonies related to the time of year, such as the opening of the academic year)

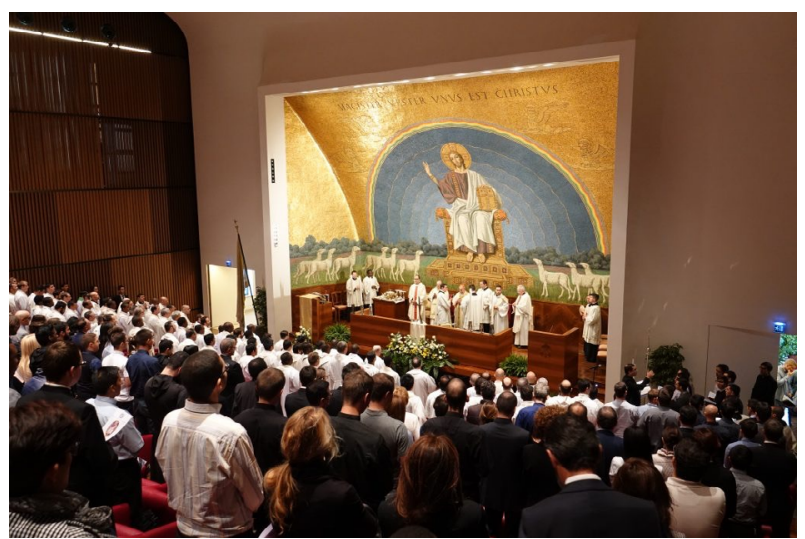

- Funeral rite

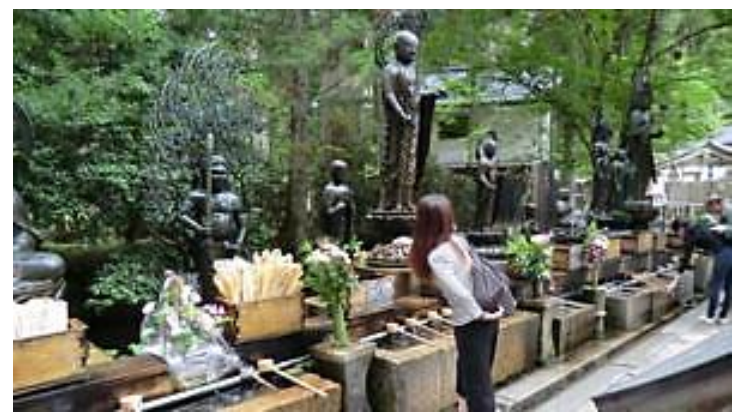




\section{PHILOSOPHICAL INHERITANCE}

The ritual can be assimilated to the notion of habit that is at the center of the traditional philosophical reflection. In this context, we must differentiate between two senses of the term:

\section{Custom as habitus}

Thomas Aquinas inherits the Aristotelian vision of habit that has a "qualitative" element (evaluation) in action. We also remember the famous book by John Dewey Human Nature and Conduct (DEwey 1921), which considers the habit as a human asset acquired in the socialization process that includes a certain order and creative elements of behavior. It is a mechanical dynamics continuously operating in our daily actions.

\section{Habit as CONSUETUdo}

Aristotle conceived the habit as a kind of mechanism that is analogous to natural mechanisms and somehow guarantees the uniform repetition of facts, acts or behavior by eliminating or reducing stress and fatigue and then making them pleasant. The habit as a repetition without reasoning is exemplarily discussed by Pascal and Hume. Bergson uses this term to describe the moral obligations as social habits that promote life and the social order. Metaphysical interpretations of the notion of habit are offered by Main de Biran, Hegel, and Ravaisson. In these cases we observe a peculiar interest in religious views. According to Hegel, the habit is fundamental for the existence of the spirituality of the individual subject; the subject can exist as a concrete subject and as soul, namely the religious content can belong to himself (with his own soul). The metaphysical perspective of Ravaisson considers the habit as a law of grace because nature reveals itself in spiritual activity. We therefore observe a natural shift from habits to rituals that can be considered as "social habits."

The philosophical debate on rituals is very interesting and present many different perspectives (SCHILBRAK 2004):

- pragmatic theory of knowledge (Rorty, Dewey, Peirce, James, Santajana, Whitehead);

- post-Wittgensteinian philosophy (Winch, Lerner, Austin, Searle, Habermas);

- existentialism (Heidegger, Sartre, Bernstein, Eliade); 
- genealogical approach (Foucault, Edge);

- phenomenology (Merleau Ponty, Dreyfus, Cross);

- cognitive science and neuroscience (Clark, Van Gelden, Varela, Frankiel, Johnson, Graybiel);

- feminist epistemology (Grosz, McGuire, Butler among others);

- comparative philosophy (Sullivan, Kasulis, Law, Coakley, Clooney, Yasuo, Nagatomo).

\section{Pragmatism}

Dewey considers does not consider rituals as a mere repetition of traditional acts but as a way to deal with a situation or a problem and to solve a conflict. They can be considered as a form of research that generates hypotheses or tends to overcome difficulties. The pragmatic logic of rituals is analyzed by Michael Raposa (1999) along the lines of the pragmatism of Peirce. Rituals are meaningful actions because they embody beliefs expressed in a certain manifest behavior. Rituals develop cognitive skills and strengthen the commonality among people by creating adequate public spaces. Rituals possess a sense for practical reason (Genres) as they represent closed models such as the Vedic rituals. Raposa rather considers them as a type of research that guides and develops cognitive skills, a spiritual model to improve human cognition .

\section{Post-Wittgensteinean Philosophy of LANGUage}

Language has a key-role according to its different uses. We do not use language only "descriptively" and different language games describe different social practices with their socially established rules (Wittgenstein). Rituals have nothing to do with knowledge about the outside world that is the prerogative of science (CIOFFI 1999). Along the lines of Wittgenstein, Peter Winch has applied a pluralistic view of language to social action study and the study of rituals. Winch and Lerner (LERNER 2002) believe that, from an epistemological point of view, it is not correct to consider rituals as irrational and unscientific behavior, because it implies to criticize a social practice from the point of view of another social practice (science). Rituals should be construed as rational relations to the context; they express an attitude about the contingencies in general rather than control or predict a particular contingency (as a disease). 
Austin and Searle have extended the realm of the "illocutionary force" by emphasizing the performative aspect of language use in different contexts (like promises or greetings). In the words of Benjamin Ray, "the performative power of the ritual language lies in its ability to reorganize and emotions to dominate the psychological forces, letting things happen in people's lives." (RAY 2000, 110). The performative power of ritual language is also at the center of Habermas' philosophy of religion, where he clearly underscores the role of extra-ordinary communication to favor empathy and solidarity (HABermas 2012).

\section{EXISTENTIALISM, HERMENEUTICS, AND PHENOMENOLOGY}

The psychological view of Ray can be expanded in an ontological and metaphysical sense. In particular, existentialism proposes the vision of the human condition as incarnate, as an active social being in the world (TODES 2001). Rituals become intelligible beyond the representationalism of Descartes (BERNSTEIN 1983). They also bridge the gap between an inaccessible inner self and social action since subjectivity is "inter-subjectivity." Finally, the experience in the world is not neutral because it is guided by projects. The body becomes central as a form of intentionality that generates knowledge in its relationship with the world. We can thus speak of ritualistic action and ritualistic knowledge as belonging to a level of intentionality that is deeper than the linguistic one. Existentialism understands rituals as merely conservative as they do not generate changes and even revolutions (LINCOLN 1989; 2000; 2003).

Hermeneutics intends action as a sort of language, as a sort of social dialogue (Gadamer, Ricœur) and Clifford Gertz's account represents an original point of view to study rituals. Geertz considers culture as an "act document" and a "sign" system so that the ethnographer's task will be to provide a vocabulary in which the ritual action can be expressed (GEerTz 1973). The point of view of interpretation is limited for not considering the perceptive and physical dimensions involved in the performance of rituals (Tyson, Stoller, Sullivan).

Differently, Foucault emphasizes the control and power of the body in the performance of rituals (FouCAULT 1980). They do not have a repressive value (Marx, Freud) but they have the power to pass through and to produce things, to induce pleasure, to form peculiar discourses. This power unfolds in a production network in the entire social body. Susan Bordo notes that 
these micro-practices put people in a position to live as a certain type of subject (BORDO 1993). The rite governs body movements, so the body becomes the inscription of cultural signs and the ritual is the central device of this inscription.

Merleau-Ponty explains how the body represents an access to the world. He emphasizes three dimensions: the conservation in the biological world, the primary actions that allow the passage from the literal to the figurative meaning as in engines attitudes of the dance and the bracketing of the biological dimension for encouraging participation in the cultural world. Along the lines of Merleau-Ponty, Crossley (1994) interprets the rituals as body techniques that embody the practical rationality because they are techniques to achieve practical results. Rituals involve knowledge of roles and social rules; for example, deference rituals embody the understanding of authority in a given society, and this explains why rituals have a crucial role in the maintenance and reproduction of societies. Crossley explains that rituals cause changes in subjective and intersubjective states, transform individual or collective ways to see the world. Rituals are techniques to relate to specific intentional states that Crossly describes in terms of emotional and imaginative intentionality.

Hubert L. and Stuart E. Dreyfus (1999) present the dimensions of corporality as:

(1) innate structures such as when the world is presented as a place to rest;

(2) acquired capacities common to all bodies such as when the world is presented as providing a place to sit and to dance;

(3) culturally acquired capacities as when the world is presented as providing a place to sit in meditation.

So even Csordas (1994) emphasizes the importance of phenomenology for the study of rituals as the hermeneutical approaches merely emphasize the semiotic aspect.

\section{Cognitive science And Neuroscience}

To understand how rituals are of importance for epistemology, cognitive science has a fundamental role and, in particular, the anti-cognitive view based on the embodied cognition. The challenge arises against the correspondence between thought and representation; internal representations are minimized (CLARK 1997) or eliminated (VAN GELDER 1995). Cognition embraces the dimensions of the nervous system, body and environment that 
influence each other by constantly and simultaneously changing to make the cognitive system a single unified system. Francisco Varela and his colleagues call the "enaction" thought that thought that "is not the representation of pre-given world by a pre-given mind but is rather the enactment of a world and a mind on the basis of a history of the variety of actions the being in the world performs." (VARELA, ThOMPSON, and Rosch 1991, 9).

The cognitive science developments are central to the study of rituals. Tamaar Frankiel (2001) hypothesized that the ritualized body is deeply related to imaginative schemes. Rituals teach people to incorporate perceptual distinctions through basic patterns such as up/down, down/up, in/out and center/ periphery. Different societies emphasize different patterns. For example, a company may focus attention on scales and hierarchies, extending and developing the pattern in its metaphors, while another focuses on the center and periphery schemes (FrankIEL 2001). This way Johnson's theory can provide a vocabulary for the comparative study of rituals that suggests how body movements shape or give rise to the thinking through rituals (see also ANDRESEN 2001). From the perspective of neuroscience, Ann Graybiel (2008) takes that rituals are culturally based preferences and reflect interactions between basal ganglia and cortical circuits that affect the social and emotional functions of the active brain.

\section{Feminist PHILOSOPHY OF RELIGION}

Feminist thought is traditionally centered on the body, but we do not find many studies on rituals even if there is a general appreciation for the bodily forms of knowledge (Grosz, McGuire). Amy Hollywood (2004) analyzes rituals from the perspective of feminist philosophy of religion and attempts to go beyond the analytical or continental traditional approaches that have mostly focused on religious beliefs rather than on rituals. Pamela Sue Anderson and Grace Jantzen have extended the bases of moral and religious reflection to the dimensions of affect, emotions and desires involved in ritual practices. Hollywood refers to the work of Marcel Mauss and Asad, who have shown that the body techniques educate people to be certain kinds of subjects and then provide a way for philosophers to develop a broader conception of practical reason. Thus, according to Hollywood, practical reason must be understood not merely as a matter of principle (for example the principle of universalization) but also as a mean to reach a broad range of objectives and thus entails acquired ways of being in the world. Hollywood illustrates how religious practice can create religious cults that provide 
experiences that make valid certain ways of life, as, for example, the meditation practices of Margaret Ebner, the German mystic of the thirteenth century.

\section{Comparative Philosophy OF RELigion}

Religious studies offer the greatest resources for the study of rituals. As pointed out by Sullivan (1990), religions do not practice their rites in a nonreflexive way. They have traditions (Buddhism, Taoism and in Islam) that analyze the nature and function of rituals. And it is certainly interesting the comparative philosophy that analyzes the mind/body relationship in terms of different perspectives (Kasulis, Nagatomo). It seems that thinking through rituals is natural for many philosophers of religion; by going beyond the social and psychological functions of rituals, ritual activities connect to the metaphysical nature of things (SCHILBRAK 2004). The Vedic rites suggest an extra-communicative nature of rituals: to follow the ritualistic rules for themselves bring pleasure beyond communicative or instrumental purposes (Staal). Thomas Kasulis intends rituals as a form of meta-practices as we can observe in Confucianism. In particular, the ancient philosopher Xunzi developed the most sophisticated approach to the value of ritual practices. The ritual tradition of Confucianism provides the means to justly order the human relationship with the cosmos. Therefore rituals have an essential relationship with ethics (GANERI 2004). Ganeri considers the interpretation of the Mimansa school about the Vedic rituals as a method of reasoning about "what should be done" (dharma) also in non-ritualistic contexts. In the Christian and Jewish traditions, rituals are the means to achieve certain goods or virtues (Taliaferro 2004) through the knowledge of ritualistic rules and plans for the future life (KEPNES 2004).

\section{RITUALS AS SOCIAL HABITS}

Routines and goal-directed behavior characterize habits both in the case of individual and social behavior (CAstelfranchi and Pezzulo 2009). We can observe ritual behavior also in non-human animals, but, in the human case, they have their expression in a different form of We-Intentionality. Moreover, they need conventional devices, that are mutually recognized through ordinary communication. Rituals have the important function to create social spaces in which individuals can share emotions, experiences, values, norms 
and knowledge. The function to share experiences is fulfilled when there exist a social space created by cooperation for reaching certain goal (Giovagnoli 2017, 22-32; Giovagnoli and Dodig-Crnkovic 2018; Giovagnoli 2020). In this context, cooperation is a kind of intersubjectivity typical of human beings who, differently from apes, are able to have "Collective Intentionality" (TomASELlo 2009), i.e. the basic intention to cooperate and therefore to reach together a certain goal. If we want to get a positive result about the extension of habits in the social dimension we need to move from a sort of goal-directed activity that we can perform together. There is a contemporary lively debate on the nature and structure of Collective Intentionality, as a necessary notion to researches in the field of social ontology (the pioneers in this area are John Searle, Raimo Tuomela, Margareth Gilbert, Michael Bratman, and Philip Pettit).

We can observe that human beings (but also other species) have the capacity to impose a function to an object so that the object acquires a function depending on the peculiar scope of the agent. The continuity between individual habits and rituals (social habits) is thus demonstrated by the fact that humans create these "agentive functions" (in Searle's terminology) in a wide variety of situations (SEARLE 2010). Also non human animals have their form of creating functions for objects but there is a fundamental difference in the concept of "function" in the human case.

We create social habits in the form of rituals by using the "status function," that is a peculiar kind of function from which we create the social world. Rituals are created by intentionality-relative functions and are characterized by two special features. They require (a) a shared intentionality namely "collective intentionality" and (b) collective imposition and recognition of a status.

The "constitutive rule" is essential to the process of constitution of institutions in general. The canonical form introduced by Searle is:

\section{Status Function $=\mathrm{X}$ counts as $\mathrm{Y}$ in $\mathrm{C}$}

For instance, a certain expression counts as promise in a certain context $\mathrm{C}$. So, it is fundamental to assign functions to objects and persons. We use ordinary language to represent state of affairs and norms, namely to understand what are the conditions of satisfaction of different speech acts (assertions, commands, promises etc.). Beyond the classical dimensions of syntax, compositionality and generativity, there is a fundamental dimension which generates public norms i.e. "deontology," which is characterized by the 
speech act of "declaration". For example, if we say "This is my house" or "This is my coach", we do not only represent a state of affairs, but we create a deontology which manifests itself in rights, obligations and duties as well as in the acceptation of the corresponding speech acts from the part of the interlocutors. This is the process by which a public deontology is created, namely public reasons for acting that are desire independent. Language does not only describe something but it creates and "partially" constitutes what it at the same time describes and creates. Representations that are partially constitutive of institutional reality, the reality of government, private property, money, universities and cocktail parties, are essentially linguistic. What must be clarified is the sense of this "partially" constitutes, because language use works on the basis of a prelinguistic dimension which embeds background capacities such as capacity to cooperate, to act as a "We". Moreover, this very capacity is fundamental to share and constitute rituals.

We pointed out the fundamental process of assigning functions to objects or to some non- physical entities, which is a form of symbolization aiming at creating institutional reality. This process is at the basis of the institutionalization of rituals and works in every community even though social practices in general are culturally characterized. Status Function apart, there are

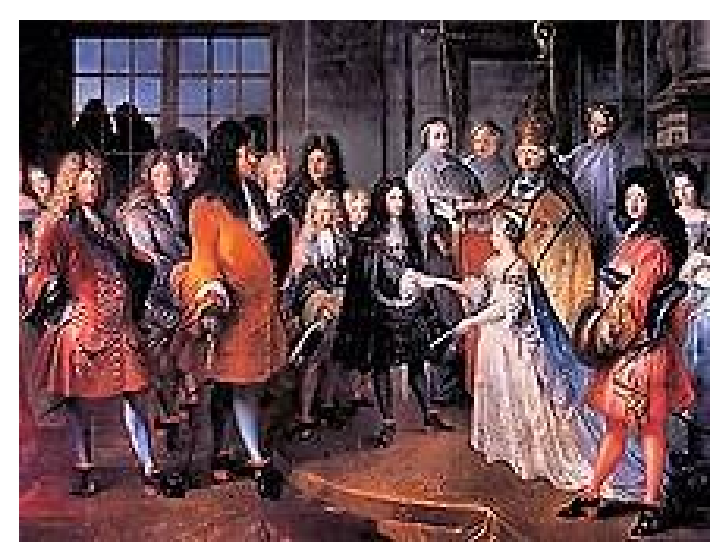
other two basic notions that occur in the explanation of a successful functioning and stability of social institutions. The first is "cooperation" as a "strong" form of Collective Intentionality and the second is "collective recognition" as a "weak form" of it. We think that these two forms of intentionality correspond to the notion of "flexibility", which implies the voluntary control over our actions and to the notion of "rigidity", which characterizes the mere following rules in the sense of routinely behavior.

We can describe a very famous example of a ritual (Searle often refers to), namely "marriage." First, we need to be moved to act in a certain way. We-Intentionality works when we want to do something together (we have a collective intention) so that we can cooperate to achieve our common goal. 
As we already anticipated, Collective Intentionality presents a weak form (collective recognition) and a strong form (cooperation). Both are crucial for rituals, in our case marriage.

Now we can see how a social transition from one status to another is performed through an institutionalized ritual:

(1) We have "collective recognition", which means that the couple simply accepts the institution of marriage prior to actually getting married.

(2) But, the actual marriage ceremony is an example of active cooperation, in which the couple enters in a new social situation acquiring new social statuses consequently.

(3) This fact obtains by the performance of the speech act of promise.

(4) The social context requires also the speech act of declaration from the part of the institutional figure who has the suitable deontic powers to celebrate the rite and to ascribe the new status to the couple.

\section{CONCLUSION}

We introduced the ongoing debate on rituals as source of fundamental knowledge about human beings and their peculiar practices. We proposed an original approach to the study of ritual that establishes a continuity of habitual behavior in the individual and social spheres. Habits and rituals require routines and goal-directed activity even though the context is different. Rituals require collective intentionality in its normative dimensions that has a fundamental role for the construction of institutions in general. They also show a kind of symbolization that can be represented in different forms: the attribution of a symbolic value to certain objects, animals and procedures. The object acquires a "status function" i.e. counts as something that can be recognized to mean something else.

\section{BIBLIOGRAPHY}

Andresen, Jensine (ed.), 2001 Religion in Mind: Cognitive Perspectives on Religious Belief, Ritual, and Experience. Cambridge: Cambridge University Press.

Bernstein, Richard J. 1983. Beyond Objectivism and Relativism: Science, Hermeneutics, and Praxis, Philadelphia: University of Pennsylvania Press.

Bordo, Susan. 1993. Unbearable Weight: Feminism, Western Culture and the Body, Berkeley: University of California Press. 
Castelfranchi, Cristiano, and Giovanni Pezzulo. 2009. "Thinking as the Control of Imagination: a Conceptual Framework for Goal-directed Systems." Psychological Research 73, no. 4: 559577.

Cioffi, Frank. 1998. Wittgenstein on Freud and Frazer. Cambridge: Cambridge University Press.

Clack, Brian R. 1999. Wittgenstein, Frazer and Religion. New York, NY: Macmillan.

Clark, Andy. 1997. Being There: Putting Brain, Body, and World Together Again. Cambridge, MA: MIT Press.

Crossley, Nick. 1994. The Politics of Subjectivity: Between Foucault and Merleau-Ponty. Avebury Series in Philosophy. Aldershot: Avebury.

Csordas, Thomas J. 1994. "Introduction: The Body as Representation and Being-in-the-world." In Embodiment and Experience: The Existential Ground of Culture and Self, edited by Thomas J. Csordas. Cambridge, MA: Cambridge University Press.

Dewey, John. 1991. Logic: The Theory of Inquiry, Carbondale, IL: Southern Illinois University Press.

Dreyfus, Hubert L., and Stuart E. Dreyfus. 1999. "The Challenge of Merleau-Ponty's Phenomenology of Embodiment for Cognitive Science." In Perspectives on Embodiment: The Intersections of Nature and Culture, edited by Gail Weiss and Hony Fern Haber. New York: Routledge.

Foucault, Michel. 1980. The History of Sexuality. Vol. 1: An Introduction. Translated by Robert Hurley. New York: Vintage Books.

Frankiel, Tamar. 2001. "Prospects in Ritual Studies." Religion 31, issue 1: 75-87.

GANERI, Jonardon. 2004. “The Ritual Roots of Moral Reason.” In Thinking through Rituals: Philosophical Perspectives, edited by Kevin Schilbrak, 207-223. London: Routledge.

GeERTZ, Clifford. 1973. The Interpretation of Culture. New York, NY: Basic Books.

Giovagnoli, Raffaela. 2017. "Lifeworld, We-Intentionality and Rituals." In Mind, Collective Agency, Norms. Essays on Social Ontology, edited by Piero Salis P. and Guido Seddone, 22-32. Aachen: Shaker Verlag.

Giovagnoli, Raffaela, and Gordana Dodig-Crnkovic (eds.). 2018. Habits and Rituals. Special Issue of Open Information Science - De Gruyter, vol. 2, issue 1.

Giovagnoli, Raffaela. 2020. "From Habits to Rituals: Rituals as Social habits." In The Logic of Social Practices, edited by Raffaela Giovagnoli and Robert Lowe. SAPERE: Studies in Applied Philosophy, Epistemology and Rational Ethics 52. Cham: Springer.

Graybiel, Ann. 2008. "Habits, Rituals and the Evaluative Brain." Annual Review of Neuroscience 31: $359-387$.

Habermas, Jürgen. 2012. Nachmetaphysiches Deneen II. Frankfurt: Suhrkamp.

Hollywood, Amy. 2004. "Rites of Passing: Foucault, Power and Same-sex Commitment Cerimonies." In Thinking through Rituals: Philosophical Perspectives, edited by Kevin Schilbrak, 52-70. London: Routledge.

JAGGAR, Alison M., and Susan R. Bordo (eds.). 1989. Gender/Body/Knowledge: Feminist Reconstructions of Being and Knowing. New Brunswick, NJ: Rutgers University Press.

Kasulis, Thomas P. 1987. "Editor's Introduction." In Yasuo YuASA. The Body: Toward an Eastern Mind-Body Theory, edited by Thomas P. Kasulis and Shigenori Nagatomo. SUNY Series in Buddhist Studies. Albany, NY: State University of New York Press. 
Kasulis, Thomas P., Roger T. Ames, and Wimal Dissanayake (eds). 1993. Self as Body in Asian Theory and Practice. The Body in Culture, History, and Religion. Albany, NY: State University of New York Press.

Kawalec, Anna. “Agency of Breath - Beyond Disciplinary Views on Ritual.” In The Logic of Social Practices, edited by Raffaela Giovagnoli and Robert Lowe, 169-185. SAPERE: Studies in Applied Philosophy, Epistemology and Rational Ethics 52. Cham: Springer, 2020.

KePNES, Steven. 2004. "Ritual and Christian Philosophy." In In Thinking through Rituals: Philosophical Perspectives, edited by Kevin Schilbrak, 224-237. London: Routledge.

Lerner, Berel Dov. 2002. Rules, Magic, and Instrumental Reason: Peter Winch's Philosophy of the Social Sciences. London: Routledge.

Lincoln, Bruce. 1989. Discourse and the Construction of Society: Comparative Studies of Myth, Ritual, and Classification. Oxford: Oxford University Press.

Lincoln, Bruce. 2000. "On Ritual, Change, and Marked Categories." Journal of the American Academy of Religion 68, no. 3: 487-510.

Lincoln, Bruce. 2003. Holy Terrors: Thinking about Religion after September 11. Chicago: University of Chicago Press.

Magnani, Lorenzo. 2018. "Ritual artifacts as Symbolic Habits." In Habits and Rituals, edited by Raffaela Giovagnoli and Gordana Dodig-CrnKovic. Special Issue of Open Information Science - De Gruyter, vol. 2, issue 1: 147.

Magnani, Lorenzo. 2009. Abductive Cognition: The Epistemological and Eco-cognitive Dimensions of Hypothetical Reasoning, chapter 1. Heidelberg, Berlin: Springer .

Nagatomo, Shigenori. 1992. "An Eastern Concept of the Body: Yuasa's Body Scheme.” In Giving the Body Its Due, edited by Maxime Sheets-Johnstone. Albany, NY: State University of New York Press.

RAPOSA, Michael L. 1999. Boredom and the Religious Imagination. Charlottesville: University of Virginia Press.

RAY, Benjamin Caleb. 2000. "Discourse about Difference: Understanding African Ritual Language." In A Magic Still Dwells: Comparative Religion in the Postmodern Age, edited by K.C. Patton and Benjamin Caleb Ray. Berkeley: University of California Press.

SchilBraK, Kevin (ed.). 2004. Thinking through Rituals: Philosophical Perspectives. London: Routledge.

SEARLE, John. 2010. Making the Social World: The Structure of Human Civilization. Oxford: Oxford University Press.

StaAl, Frits. 1982. The Science of Ritual, Poona, India: Bhandarkar Oriental Research Institute.

Stoller, 1997. Paul. Sensuous Scholarship. Philadelphia: University of Pennsylvania Press.

Sullivan, Lawrence E. 1990. "Body Works: Knowledge of the Body in the Study of Religion." History of Religions 30: 86-99.

Sullivan, Lawrence E. 1979. "A Performative Approach to Ritual." Proceedings of the British Academy 65: 113-69.

TAliAfERro, Charles. 2004. "Religious Rituals, Spiritually Disciplined Practices and Health." In Thinking through Rituals: Philosophical Perspectives, edited by Kevin Schilbrak, 238-250. London: Routledge.

ToDEs, Samuel. 2001. Body and World. Cambridge, MA: MIT Press.

Tomasello, Michael. 2009. Why We Cooperate. Cambridge, MA: MIT Press. 
Tyson, R.W., Jr. 1988. “Culture's 'Hum and Buzz' of Implication: The Practice of Ethnography and the Provocations of Clifford Geertz's Thick Descriptions.” Soundings 71: 95-111.

VAN Gelder, T. 1995. "What Might Cognition Be, If Not Computation?" Journal of Philosophy 92: 345-381.

Varela, Francisco J., Evan Thompson, and Eleonor Rosch. 1991. The Embodied Mind: Cognitive Science and Human Experience. Cambridge, MA.: MIT Press.

WINch, Peter. 1958. The Idea of a Social Science and its Relation to Philosophy, London: Routledge $\&$ Kegan Paul.

WINCH, Peter. 1970. “Understanding a Primitive Society.” In Rationality, edited by Bryan Wilson. Oxford: Blackwell.

\section{RITUALS: PHILOSOPHICAL PERSPECTIVES AND NORMATIVE ASPECTS}

\section{S u m m a ry}

We use the word "rite" or "ritual" especially in relation to religion and myth to indicate those aspects of it that make religious experience possible in the mystical dimension. Rituals are presented as sets of acts or normatively codified practices that form cultural patterns of a given society and are a representation of the cultural values and standards. They are fundamental for the institutionalization of roles, the formation of social identity and social cohesion. We'll sketch several philosophical perspectives to show conceptual differences and theoretical views concerning the notion of ritual and its normative aspects.

Keywords: rite; ritual; religion; myth; codified practices; cultural patterns; cultural values; cultural standards; philosophical perspectives; normative aspects.

\section{RYTUAŁY: PERSPEKTYWY FILOZOFICZNE I ASPEKTY NORMATYWNE}

\section{Streszczenie}

Używamy słów „ryt” lub „rytuał”, zwłaszcza w odniesieniu do religii i mitu, aby wskazać te aspekty, które umożliwiają doświadczenie religijne w wymiarze mistycznym. Rytuały przedstawiane są jako zbiory aktów lub normatywnie skodyfikowanych praktyk, które kształtują wzorce kulturowe danego społeczeństwa i są reprezentacją wartości i standardów kulturowych. Mają fundamentalne znaczenie dla instytucjonalizacji ról, kształtowania społecznej tożsamości i spójności. Szkicujemy kilka perspektyw filozoficznych, aby pokazać różnice koncepcyjne i poglądy teoretyczne dotyczące pojęcia rytuału i jego normatywnych aspektów.

\section{Przełożyt Stanisław Sarek}

Slowa kluczowe: ryt; rytuał; religia; mit; skodyfikowane praktyki; wzorce kulturowe; wartości kulturowe; standardy kulturowe; perspektywy filozoficzne; aspekty normatywne 